FACTA UNIVERSITATIS

Series: Physical Education and Sport, Vol. 18, No 1, 2020, pp. 83 - 92

https://doi.org/10.22190/FUPES190918008A

Research article

\title{
ECONOMIC EFFECTS OF INJURIES IN ELITE SOCCER PLAYERS WITH REGARD TO ANKLE INJURY
}

\author{
UDC 796:323 \\ 61:001
}

\section{Tawfiq Hassan Abdolkarim Alhdad, Predrag Gavrilović ${ }^{2}$, Dragan Životic ${ }^{3}$}

${ }^{1}$ Faculty of Management in Sport, Alfa BK University, Belgrade, Serbia

${ }^{2}$ Center for Medical Informatics, Belgrade, Serbia

${ }^{3}$ Faculty of Physical Culture and Sports Management, Singidunum University, Belgrade,

Serbia

\begin{abstract}
The main aim of the current research is to determine the differences and correlations of sport seasons and economic statistics between the highest paid soccer players in the world, with an ankle injury in addition to other injuries and without an ankle injury. By comparing highest paid soccer players in the world (N=95), i.e., a sub-sample of players with an ankle injury $(N=44)$, and a sub-sample of players without an ankle injury $(N=51)$, it is possible to conclude that significant differences were not found in the variables of age, market value, the number of matches completed, the number of goals scored and the number of assists, as well as in the derived variables of the value of one player's day and the value of one match. In the basic variables the number of days missed due to injuries $(222.61 \pm 165.61$ vs 124.98 \pm 110.59$)$, the number of seasons with injuries $(5.68 \pm 2.23 \mathrm{vs}$ $4.53 \pm 2.73)$ and the number of matches missed due to injuries $(35.32 \pm 28.07$ vs 20.12 \pm 19.2$)$, as well as in the derived variables of number of days missed due to injuries per year (40.4 \pm 29.33 vs 27.16 \pm 18.18$)$, number of games missed due to injuries per year $(6.23 \pm 3.83$ vs 4.32 \pm 3.21$)$, value of days missed due to injuries $(£ 7,627 \pm £ 5,898 \mathrm{vs} £ 5,070 \pm £ 3,634)$ and

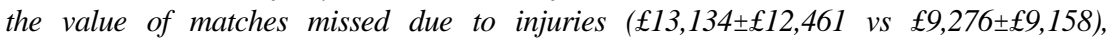
statistically significant differences were determined. All determined values were higher in the sub-sample of players who, in addition to other injuries, suffered from an ankle injury as well. In the multivariate exploration of the structure of the basic research variables, the results obtained indicate a latent space that had an interpretable three-dimensional structure. The structure of the space indicated a functionally independent relationship between the frequency and intensity of injury, on the one hand, and the chronological age, the value of the transfer and the player's efficacy on the other. It can be concluded that
\end{abstract}

Received September 18, 2019/ Accepted May 06, 2020

Corresponding author: Tawfiq Hassan Abdolkarim Alhdad

Faculty of Management in Sport, Alfa BK University, Palmira Toljatija 3, 11070 Novi Beograd, Serbia

Phone: + $381112674164 \cdot E-m a i l:$ tawfikhasan68@yahoo.com 
sports injuries, and ankle injuries especially in elite soccer players, have significant economic reprisals.

Key words: Sports Injuries, Ankle Sprain, Economic Consequences of Injury

\section{INTRODUCTION}

Engaging in sports activities is also associated with an increased incidence of injuries, among which the ankle injury is the most common. Movements involving the ankle osteoarticular and muscular structures are the basis of competitive and training activities in most sports and sports disciplines, such as football, basketball, volleyball, handball, athletics, etc. (McKay, Goldie, Payne, \& Oakes, 2001; Anandacoomarasamy \& Barnsley, 2005; Beynnon, Vacek, Murphy, Alosa, \& Paller, 2005; Hubbard \& Hicks-Little, 2008; Achenbach et al., 2018).

Ankle injury occurs in three modalities: stretching, partial and complete rupture of at least one of the ligaments that stabilize the ankle structures and provide proprioceptive information (Doherty et al., 2014; Gribble et al., 2016a, 2016b). Repeated joint injuries can lead to functional disorders in the form of joint instability, loss of proprioception, significant impairment of locomotor potentials, early degenerative processes on the bones and chronic pain. It has been shown that only about one-fourth of injured patients recover fully, without pain, swelling and decreased functional potential in the ankle structures. Other injured individuals have problems that persist for at least two years after the injury (Cruz, Oliveira, \& Silva, 2020).

In football, lower extremity injuries occur in $67 \%$ to $88 \%$ of cases, with ankle injury being most common in both men and women (Östenberg \& Roos, 2000; Waldén, Hägglund, \& Ekstrand, 2005, 2007; Dvorak, Junge, Grimm, \& Kirkendall, 2007; Hägglund, Walden, \& Ekstrand, 2007; Pierpoint, LaBella, Collins, Fields, \& Comstock, 2018).

An analysis of 1524 injuries in 637446 people training football revealed the most frequent injuries during the competition and an incidence of 4.77 injuries per 1000 people/competitions, while this incidence is significantly lower in training activities and is 1.37 per 1000 people/training (Yard, Schroeder, Fields, Collins, \& Comstock, 2008).

Injuries are the most common during matches, and are $100 \%$ to $300 \%$ more frequent than training injuries (Poulsen, Freund, Madsen, \& Sandvej, 1991; Dvorak \& Junge, 2000). The highest number of sports injuries, about 50\%, are a consequence of excessive load, i.e., of disproportion between the athlete's ability and what is expected from him (Krstić \& Stamatović, 2018). According to the available data, in football the incidence of injury increases with increasing fatigue in players. Thus, injury in the second half of the match is more frequent than injury in the first. In addition, injuries were found to be reduced in the first 15 minutes of the match, while increasing markedly in the last 15 minutes of the second half (Dvorak et al., 2007; Tscholl et al., 2007; Tscholl, O'Riordan, Fuller, Dvorak, \& Junge, 2000).

Today, especially in the field of top competitive sports, the phenomenon of injury has its very pronounced economic component. The amounts exchanging hands during transfers, as well as of other athletes' incomes in the most lucrative sports, indicate the extremely high "prices" of injuries that prevent these athletes from participating in the competition system. Every day of absence from training has a high price, and especially high prices for 
absenteeism from matches and competitions, for which fans, donors and sponsors, as well as the entire related industry of goods and services, participate in the sports organization's costs.

Failure to appear by an elite soccer player, basketball player, tennis player, etc. automatically leads to a decline in interest in a sporting event and results in significantly lower revenues than expected.

The financial implications of ankle injury are vividly illustrated by the fact that the estimated economic burden created by 250000 annual sprains in US can amount to \$2-4 billion annual costs, thus creating an economic burden on the global health care systems (Waterman, Owens, Davey, Zacchilli, \& Belmont Jr, 2010). These primary, immediate costs of injury should be accompanied by the costs of osteoarthritis medical care, which occurs frequently and develops over the life of previously injured athletes (Englund, Roos, \& Lohmander, 2003; Roos, 2005; Ezzat, Brussoni, Whittaker, \& Emery, 2018).

The main aim of the current research is to determine differences and correlations between sport season and economic statistics between the highest paid soccer players in the world, with an ankle injury in addition to other injuries and without an ankle injury.

\section{METHODS}

The research was conceived as an exploratory cross-sectional study with parallel groups on an initial sample, consisting of the 100 highest paid soccer players in the world (Transfermarkt, 2019). As all the required information was not available for 5 soccer players, and the basic sample was reduced to 95 respondents. The study sub-samples were formed under the criterion of ankle injury: a sub-sample of soccer players with an ankle injury in addition to other injuries ( $\mathrm{SS} 1, \mathrm{~N}=44$ ) and a sub-sample of soccer players who had not injured their ankle (SS2, N=51). The basic and derived variables in the study are presented in Table 1.

Table 1 Basic and derived variables observed in the research

\begin{tabular}{ll}
\hline Basic variables & Abbreviation \\
\hline Age & Age \\
Market Value & Market Value (£) \\
Match Played & Match \\
Goals Scored & Goals \\
Assists & Assists \\
Number of Days Missed Due to Injuries & Days_Inj \\
Number of Seasons with Injuries & Years_Inj \\
Number of Matches Missed Due to Injuries & Match_Inj \\
\hline Derived variables & \\
\hline Number of Days Missed Due to Injuries per Year & Days_Inj/Year \\
Number of Matches Missed Due to Injuries per Year & Match_Inj/Year \\
Value of One Player's Day & Day_Val (£) \\
Value of One Match & Match_Val (£) \\
Value of Days Missed Due to Injuries & Inj_Day_Val $(£)$ \\
Value of Matches Missed Due to Injuries & Inj_Match_Val (£) \\
\hline
\end{tabular}


All data were processed using descriptive, inferential and multivariate statistical methods. Descriptive statistical analysis determined the minimum and maximum values, mean values and standard deviations for the baseline sample, as well as for the sub-samples of the survey. Testing for significance of the differences between the sub-samples in the observed variables was performed by Mann Whitney's U-test. In the domain of multivariate analysis, factor analysis of the manifest space of the observed, basic variables was performed using the principal components method. A number of significant factors were determined according to the Kaiser Guttman criterion, and the initial factor solution was brought to the most interpretable form by rotation according to the Varimax criterion.

\section{RESULTS}

Table 2 Results of the descriptive statistics and Mann Whitney U-Test

\begin{tabular}{|c|c|c|c|c|c|c|c|c|c|c|}
\hline \multirow[t]{2}{*}{ Variables } & \multicolumn{3}{|c|}{$\begin{array}{l}\text { Basic sample } \\
\quad(n=95)\end{array}$} & \multicolumn{3}{|c|}{$\begin{array}{l}\text { With an ankle injury } \\
\qquad(\mathrm{n}=44)\end{array}$} & \multicolumn{3}{|c|}{$\begin{array}{l}\text { Without an ankle injury } \\
\qquad(\mathrm{n}=51)\end{array}$} & \multirow{2}{*}{$\frac{\mathrm{M}-\mathrm{W}}{\mathrm{p}}$} \\
\hline & Min & Max & $\begin{array}{c}\text { Mean } \\
\pm \mathrm{SD}\end{array}$ & Min & Max & $\begin{array}{c}\text { Mean } \\
\pm \mathrm{SD}\end{array}$ & Min & Max & $\begin{array}{c}\text { Mean } \\
\pm \mathrm{SD}\end{array}$ & \\
\hline Age & 18 & 34 & $\begin{array}{l}25.13 \\
\pm 2.99\end{array}$ & 20 & 34 & $\begin{array}{l}25.3 \\
\pm 2.9\end{array}$ & 18 & 32 & $\begin{array}{c}24.98 \\
\pm 3.1\end{array}$ & 0.780 \\
\hline Market Value (£) & 45.000 & 180.000 & $\begin{array}{c}69.537 \\
\pm 27.149\end{array}$ & 45.000 & 180.000 & $\begin{array}{c}70.875 \\
\pm 32.292\end{array}$ & 45.000 & 144.000 & $\begin{array}{c}68.382 \\
\pm 22.046\end{array}$ & 0.407 \\
\hline Match & 12 & 50 & $\begin{array}{l}35.79 \\
\pm 6.22\end{array}$ & 17 & 50 & $\begin{array}{l}35.75 \\
\pm 6.45\end{array}$ & 12 & 45 & $\begin{array}{l}35.82 \\
\pm 6.08\end{array}$ & 0.967 \\
\hline Goals & 0 & 34 & $\begin{array}{c}8.29 \\
\pm 8.28\end{array}$ & 0 & 31 & $\begin{aligned} & 8.8 \\
\pm & 8.71\end{aligned}$ & 0 & 34 & $\begin{array}{r}7.86 \\
\pm 7.94\end{array}$ & 0.526 \\
\hline Assists & 0 & 19 & $\begin{array}{c}5.73 \\
\pm 4.96\end{array}$ & 0 & 19 & $\begin{array}{c}6.11 \\
\pm 4.86\end{array}$ & 0 & 19 & $\begin{array}{c}5.39 \\
\pm 5.06\end{array}$ & 0.315 \\
\hline Days_Inj & 3 & 825 & $\begin{array}{c}170.2 \\
\pm 146.45\end{array}$ & 15 & 825 & $\begin{array}{c}222.61 \\
\pm 165.61\end{array}$ & 3 & 499 & $\begin{array}{c}124.98 \\
\pm 110.59\end{array}$ & $0.001^{*}$ \\
\hline Years_Inj & 1 & 14 & $\begin{array}{c}5.06 \\
\pm 2.56\end{array}$ & 1 & 10 & $\begin{array}{c}5.68 \\
\pm 2.23\end{array}$ & 1 & 14 & $\begin{array}{c}4.53 \\
\pm 2.73\end{array}$ & $0.008^{*}$ \\
\hline Match_Inj & 0 & 139 & $\begin{array}{c}27.16 \\
\pm 24.79\end{array}$ & 4 & 139 & $\begin{array}{c}35.32 \\
\pm 28.07\end{array}$ & 0 & 94 & $\begin{array}{l}20.12 \\
\pm 19.2\end{array}$ & $0.001^{*}$ \\
\hline Days_Inj/Year & 1 & 165.5 & $\begin{array}{c}33.29 \\
\pm 24.76\end{array}$ & 9.5 & 165.5 & $\begin{array}{c}40.4 \\
\pm 29.33\end{array}$ & 1 & 90.33 & $\begin{array}{c}27.16 \\
\pm 18.18\end{array}$ & $0.017^{*}$ \\
\hline Match_Inj/Year & 0 & 16.33 & $\begin{array}{c}5.21 \\
\pm 3.62\end{array}$ & 1.71 & 16.25 & $\begin{array}{c}6.23 \\
\pm 3.83\end{array}$ & 0 & 16.33 & $\begin{array}{c}4.32 \\
\pm 3.21\end{array}$ & $0.012^{*}$ \\
\hline $\begin{array}{l}\text { Day_Value } \\
\text { (£) }\end{array}$ & 123 & 493 & $\begin{array}{c}191 \\
\pm £ 74\end{array}$ & 123 & 493 & $\begin{array}{c}194 \\
\pm £ 88\end{array}$ & 123 & 395 & $\begin{array}{c}187 \\
\pm £ 60\end{array}$ & 0.407 \\
\hline $\begin{array}{l}\text { Match_Value } \\
\text { (£) }\end{array}$ & 1.071 & 5.870 & $\begin{array}{l}2.007 \\
\pm £ 902\end{array}$ & 1.071 & 5.586 & $\begin{array}{l}2.022 \\
\pm \pm 919\end{array}$ & 1.125 & 5.870 & $\begin{array}{r}1.993 \\
\pm £ 896\end{array}$ & 0.797 \\
\hline $\begin{array}{l}\text { Inj_Day_Value } \\
(£)\end{array}$ & 123 & 29.441 & $\begin{array}{c}6.254 \\
\pm £ 4.958\end{array}$ & 1.171 & 29.441 & $\begin{array}{c}7.627 \\
\pm £ 5.898\end{array}$ & 123 & 15.592 & $\begin{array}{c}5.070 \\
\pm £ 3.634\end{array}$ & $0.022^{*}$ \\
\hline $\begin{array}{l}\text { Inj_Match_Value } \\
(£)\end{array}$ & 0 & 71.690 & $\begin{array}{r}11.063 \\
\pm £ 10.926 \\
\end{array}$ & 2.250 & 71.690 & $\begin{array}{r}13.134 \\
\pm £ 12.461 \\
\end{array}$ & 0 & 45.500 & $\begin{array}{r}9.276 \\
\pm £ 9.158 \\
\end{array}$ & $0.029^{*}$ \\
\hline
\end{tabular}


By comparing the sub-samples of the research of soccer players who, besides other injuries, had an ankle injury with a sub-sample of soccer players who had not sustained this type of injury (Table 2), it can be concluded that no significant differences were found in the basic variables Age, Market Value (£), Matches Played, Goals Scored and Assists. For this reason, no statistically significant difference was recorded in the variables derived from the Value of One Player's Day (Day Value $£$ ) and the Value of One Match (Match Value $£$ ).

In the basic variables, the Number of Days Missed Due to Injuries (Days_Inj, $222.61 \pm 165.61$ vs $124.98 \pm 110.59$ ), the Number of Seasons with Injuries (Years_Inj, $5.68 \pm 2.23$ vs $4.53 \pm 2.73$ ) and the Number of Matches Missed Due to Injuries (Match_Inj, $35.32 \pm 28.07$ vs $20.12 \pm 19.2$ ), statistically significant differences between the research subsamples were determined, and in the direction of higher value in the sample of players who, in addition to other injuries, had injuries to the ankle. These differences also produced statistically significant differences in the derived variables: Number of Days Missed Due to Injuries per Year (Days_Inj/Year, 40.4 \pm 29.33 vs 27.16 \pm 18.18 ), Number of Matches Missed Due to Injuries per Year (Match_Inj/Year, 6.23 \pm 3.83 vs 4.32 \pm 3.21 ), Value of Days Missed Due to Injuries (Inj_Day_Value $£, 7,627 \pm 5,898$ vs $£ 5,070 \pm £ 3,634$ ) and Value of Matches Missed Due to Injuries (Inj_Match_Value $£, £ 13,134 \pm £ 12,461$ vs $£ 9,276 \pm £ 9,158$ ). In the case of the derived variables, all determined values were higher for the sub-sample of athletes who, in addition to other injuries, had an ankle injury.

Table 3 Factor analysis results

\begin{tabular}{lccc}
\hline \multirow{2}{*}{ Variables } & \multicolumn{3}{c}{ Factor loads } \\
\cline { 2 - 4 } & 1. factor & 2. factor & 3. factor \\
\hline Age & 0.382 & 0.039 & $0.808^{*}$ \\
Market value (£) & 0.138 & $0.794^{*}$ & 0.043 \\
Matches & -0.473 & 0.252 & $0.627^{*}$ \\
Goals & 0.059 & $0.865^{*}$ & 0.146 \\
Assists & -0.019 & $0.837^{*}$ & 0.059 \\
Days_Inj & $0.936^{*}$ & 0.044 & 0.011 \\
Years_Inj & $0.766^{*}$ & 0.163 & 0.397 \\
Match_Inj & $0.951^{*}$ & 0.080 & -0.022 \\
AIGEN & 3.008 & 2.143 & 1.020 \\
VARIANCE & 0.345 & 0.272 & 0.154 \\
CUMULATIVE & 0.345 & 0.617 & 0.771 \\
\hline
\end{tabular}

Legend: ${ }^{*}$ - salient value

The inter-functional relationships between the 8 observed variables, which are related to selected indicators of economic aspects of injuries in the highest paid soccer players, common to the basic sample, were determined by a correlation analysis (Table 3 ). Due to the possible effect of nonspecific and error factors on the indicators analyzed, factorization of the correlation matrices of the basic variables was performed in order to obtain a parsimony structure, which would retain all significant functional relationships, but now decontaminated by the influence of the error factors. In this sense, the factor analysis was performed using the principal components method.

Only the basic variables were retained for analysis because inclusion of the derived variables, due to their linear relationship with the variables from which they were derived, would lead to the collapse of the correlation matrix that was subject to factorization. 
Within the space defined by 8 observed (manifest) variables, a factor analysis was conducted, the results of which support the latency of 3 latent variability generators, which can be interpreted as the basic dimensions of the analyzed space. The extracted dimensions are responsible for $77.1 \%$ of the total variance registered (Table 3).

In the latent dimension model of the analyzed space, the first Varimax factor extracted $34.5 \%$ of the total registered variance (Table 3 ). The most promising values were projected on this factor by three manifest variables: Number of Days Missed Due to Injuries (Days_Inj, 0.936), Number of Seasons with Injury (Years_Inj, 0.766), and Number of Matches Missed Due to Injuries (Matches_Inj, 0.951). In addition to the above variables, there were statistically significant but non-salient projections of the Matches Played (-0.473) and Age (0.382) variables on this factor. The structure of the variables that were saturated with this factor speaks to the frequency of injury to the soccer player, and thus can be interpreted. It is of interest to note certain functional relationships with the number of matches played, which are negative, i.e. more frequent injury is associated with fewer games played in the season, while more frequent injury in a certain functional relationship is of lower intensity for the age of the soccer player. So, older athletes have a slightly increased likelihood of injury, which will exclude them from the games.

In the model of latent dimensions of the analyzed space, the second Varimax factor extracted $27.2 \%$ of the total registered variance (Table 3 ). The most promising values were projected on this factor by three manifest variables: Market Value $£(0.794)$, Goals scored (0.865) and Assists (0.837). The construction of this factor points to strong functional links that describe the effectiveness of the soccer player's performance, estimated by the goals scored, or assists from which the goals came, which is related to the market value of the players. For these reasons, the factor can be interpreted as a dimension of the player's efficiency.

In the latent dimension model of the analyzed space, the third Varimax factor extracted $15.4 \%$ of the total registered variance (Table 3 ). The most promising values were the manifest variables Age (0.808) and Matches played (0.627). In addition to the above variables, this factor had a statistically significant but non-salivary projection and the variable Number of Seasons with Injuries (Years_Inj, 0.397). Variables saturated with the third extracted factor, with their functional connections, indicate a higher number of matches played in the season by older players. This link is in support of the conclusion that older, and therefore more experienced players, form the framework of strategic and tactical solutions coaches devise with their team. The sporadic relationship with the variable related to the frequency of injury is due to the previously discussed functional relationships in the structure of the first extracted factor. Finally, this latent dimension of the analyzed space can be interpreted as a factor of performing experience. 


\section{DISCUSSION}

In relation the descriptive statistical analysis and the analysis of quantitative differences between the sub-samples of soccer players who have or do not have ankle injuries, it should be pointed out that the ankle injury is not in the function of chronological age, or in the function of the athletes' performance efficiency, but that significantly different indicators register abstinence from training and competition with soccer players who injure their ankle, relative to other injuries that athletes sustained. Namely, when the ankle is injured, there is a significantly longer time interval of absence from the sports grounds for an athlete. This data, in conjunction with the fact that observational sub-models do not differ significantly in revenue and athlete performance indicators estimated by the number of goals scored and assists provided, indicates a manifestation of statistically significant differences in financial losses, both in terms of lost training days and in value lost by matches missed.

These results are in conflict with the results of a study in which the length of being engaged in soccer, which is related to the quality of the league in which the athletes perform, has a significant impact on the incidence of injury. These results support the conclusion that long-term soccer involvement has been reduced by a decreased risk of injury by $38 \%$ to $48 \%$ (Poulsen et al., 1991). Disagreement was observed with respect to research findings in which the age of soccer players was isolated as one of the factors that significantly influence the incidence of injury (Kucera, Marshall, Kirkendall, Marchak, \& Garrett Jr, 2005). Research findings have indicated a higher likelihood of injury among older athletes, which has not been observed in the female population (Faude, Junge, Kindermann, \& Dvorak, 2005).

This discrepancy can be explained by the pronounced homogeneity of the sample analyzed in this study. Specifically, it is expected that extending the survey sample to populations of lower quality players could produce different results.

According to some authors, the severity of injury can be estimated by the number of days absent from training and competition (Fuller et al., 2006). Thus, injuries not preventing athletes from participating in training and competition are treated as minor. Injuries that disable soccer players in their activities for one to three days are considered to be minimal. There are moderate injuries that remove players from the field from 4 up to 7 days. Medium-weight injuries qualify pathological conditions that disable players from 8 to 28 days, while injuries that prevent players from training and competing for more than 28 days are considered severe. Of the total injuries of players of all ages, they account for $10 \%$ to $25 \%$ of the total number of injuries.

Top-level competitive sports have become one of the most important leisure activities, during which spectators, fans and devotees follow sports events around the world (Andreff, 2015; McColl-Kennedy \& Fetter, 2001). Media penetration and the presence of sports content provides access to the widest range of potential consumers, which is why advertising resources in electronic and print media reach astronomical values (McCollKennedy \& Fetter, 2001; Lefever, 2012). 


\section{CONCLUSION}

It is possible to conclude that factor analysis of selected indicators of economic aspects of injury among the highest paid soccer players in the world produced an interstable structure of space determined by three basic dimensions. It is of interest to the research that the frequency of injury has no significant functional links with the experience and player effectiveness of the highest paid soccer players in the world, but is the result of the operation of latent generators of variability independent of players' income, their chronological and sports' performance age.

Finally, the research findings indicate the pronounced economic importance of injuring elite soccer players, with ankle injury being an additional factor that significantly increases negative economic indicators of injury.

\section{REFERENCES}

Andreff, W. (2015). The Tour de France: a success story in spite of competitive imbalance and doping. In D. Van Reeth \& D. Larson (Eds.). The economics of professional road cycling, (pp. 233-255), Springer: New York

Achenbach, L., Loose, O., Laver, L., Zeman, F., Nerlich, M., Angele, P., et al. (2018). Beach handball is safer than indoor team handball: Injury rates during the 2017 European Beach Handball Championships. Knee Surgery, Sports Traumatology, Arthroscopy, 26(7), 1909-1915.

Anandacoomarasamy, A., \& Barnsley, L. (2005). Long term outcomes of inversion ankle injuries. British Journal of Sports Medicine, 39(3), e1-e4.

Beynnon, B. D., Vacek, P. M., Murphy, D., Alosa, D., \& Paller, D. (2005). First-time inversion ankle ligament trauma: The effects of sex, level of competition, and sport on the incidence of injury. American Journal of Sports Medicine, 33(10), 1485-1491.

Doherty, C., Delahunt, E., Caulfield, B., Hertel, J., Ryan, J., \& Bleakley, C. (2014). The incidence and prevalence of ankle sprain injury: A systematic review and meta-analysis of prospective epidemiological studies. Sports Medicine, 44(1), 123-140.

Dvorak, J., \& Junge, A. (2000). Football injuries and physical symptoms. A review of the literature. American Journal of Sports Medicine, 28(Suppl.), S3-S9.

Dvorak, J., Junge, A., Grimm, K., \& Kirkendall, D. (2007). Medical report from the 2006 FIFA World Cup Germany. British Journal of Sports Medicine, 41(9), 578-581.

Cruz, A., Oliveira, R., \& Silva, A.G. (2020). Functional ankle instability prevalence and associated risk factors in male football players. Open Journal of Orthopedics, 10(04), 77-92.

Englund, M., Roos, E. M., \& Lohmander, L. S. (2003). Impact of type of meniscal tear on radiographic and symptomatic knee osteoarthritis: A sixteen-year followup of meniscectomy with matched controls. Arthritis and Rheumatism, 48(8), 2178-2187.

Ezzat, A. M., Brussoni, M., Whittaker, J. L., \& Emery, C. A. (2018). A qualitative investigation of the attitudes and beliefs about physical activity and post-traumatic osteoarthritis in young adults 3-10 years after an intra-articular knee injury. Physical Therapy in Sport, 32, 98-108.

Faude, O., Junge, A., Kindermann, W., \& Dvorak, J. (2005). Injuries in female soccer players: A prospective study in the German national league. American Journal of Sports Medicine, 33(11), 1694-1700.

Fuller, C. W., Ekstrand, J., Junge, A., Andersen, T. E., Bahr, R., Dvorak, J., et al. (2006). Consensus statement on injury definitions and data collection procedures in studies of football (soccer) injuries. British Journal of Sports Medicine, 40(3), 193-201.

Gribble, P. A., Bleakley, C. M., Caulfield, B. M., Docherty, C. L., Fourchet, F., Fong, D. T. P., et al. (2016a). 2016 consensus statement of the International Ankle Consortium: Prevalence, impact and long-term consequences of lateral ankle sprains. British Journal of Sports Medicine, 50(24), 1493-1495.

Gribble, P. A., Bleakley, C. M., Caulfield, B. M., Docherty, C. L., Fourchet, F., Fong, D. T. P., et al. (2016b). Evidence review for the 2016 International Ankle Consortium consensus statement on the prevalence, impact and long-term consequences of lateral ankle sprains. British Journal of Sports Medicine, 50(24), 1496-1505. 
Hägglund, M., Walden, M., \& Ekstrand, J. (2007). Lower reinjury rate with a coach-controlled rehabilitation program in amateur male soccer: A randomized controlled trial. American Journal of Sports Medicine, 35(9), 1433-1442.

Transfermarkt (2019). Most valuable players. Retrieved March 10, 2019 from the World Wide Web: https://www.transfermarkt.com

Hubbard, T. J., \& Hicks-Little, C. A. (2008). Ankle ligament healing after an acute ankle sprain: An evidencebased approach. Journal of Athletic Training, 43(5), 523-529.

Krstić, O., \& Stamatovic, M. (2018). Physical treatment of sports knee injuries. Facta Universitatis Series Physical Education and Sport, 16(1), 211-220.

Kucera, K. L., Marshall, S. W., Kirkendall, D. T., Marchak, P. M., \& Garrett Jr, W. E. (2005). Injury history as a risk factor for incident injury in youth soccer. British Journal of Sports Medicine, 39(7), 462-466.

Lefever, K. (2012). Specificity of sport: The important role of sport in society. In New Media and Sport, (pp. 31-53). TMC Asser Press, The Hague, The Netherlands.

McColl-Kennedy, J. R., \& Fetter, R. E. (2001). An empirical examination of the involvement to external search relationship in services marketing. Journal of Services Marketing, 15(2), 82-98.

McKay, G. D., Goldie, P. A., Payne, W. R., \& Oakes, B. W. (2001). Ankle injuries in basketball: Injury rate and risk factors. British Journal of Sports Medicine, 35(2), 103-108.

Östenberg, A., \& Roos, H. (2000). Injury risk factors in female European football. A prospective study of 123 players during one season. Scandinavian Journal of Medicine and Science in Sports, 10(5), 279-285.

Pierpoint, L.A., LaBella, C.R., Collins, C.L., Fields, S.K., \& Comstock, R.D. (2018). Injuries in girls' soccer and basketball: a comparison of high schools with and without athletic trainers. Injury Epidemiology, 5, 29, https://doi.org/10.1186/s40621-018-0159-6.

Poulsen, T. D., Freund, K. G., Madsen, F., \& Sandvej, K. (1991). Injuries in high-skilled and low-skilled soccer: a prospective study. British Journal of Sports Medicine, 25(3), 151-153.

Roos, E. M. (2005). Joint injury causes knee osteoarthritis in young adults. Current Opinion in Rheumatology, 17(2), 195-200.

Tscholl, P., O'Riordan, D., Fuller, C. W., Dvorak, J., Gutzwiller, F., \& Junge, A. (2007). Causation of injuries in female football players in top-level tournaments. British Journal of Sports Medicine, 41(Suppl. 1), i8-i14.

Tscholl, P., O'Riordan, D., Fuller, C. W., Dvorak, J., \& Junge, A. (2007). Tackle mechanisms and match characteristics in women's elite football tournaments. British Journal of Sports Medicine, 41(Suppl. 1), i15-i19.

Waldén, M., Hägglund, M., \& Ekstrand, J. (2005). UEFA Champions League study: A prospective study of injuries in professional football during the 2001-2002 season. British Journal of Sports Medicine, 39(8), 542-546.

Waldén, M., Hägglund, M., \& Ekstrand, J. (2007). Football injuries during European Championships 20042005. Knee Surgery, Sports Traumatology, Arthroscopy, 15(9), 1155-1162.

Waterman, B. R., Owens, B. D., Davey, S., Zacchilli, M. A., \& Belmont Jr, P. J. (2010). The epidemiology of ankle sprains in the United States. JBJS, 92(13), 2279-2284.

Yard, E. E., Schroeder, M. J., Fields, S. K., Collins, C. L., \& Comstock, R. D. (2008). The epidemiology of United States high school soccer injuries, 2005-2007. American Journal of Sports Medicine, 36(10), 1930-1937.

\section{EKONOMSKI EFEKTI POVREDA VRHUNSKIH FUDBALERA U ODNOSU NA POVREDU SKOČNOG ZGLOBA}

Glavni cilj aktuelnog istraživanja je da se utvrde razlike $i$ korelacije u statistici sportske sezone $i$ ekonomskoj statistici između najplaćenijih fudbalera na svetu, sa povredom skočnog zgloba pored ostalih povreda i bez povrede skočnog zgloba. Upoređujući najbolje plaćene fudbalere na svetu (N=95), tj. subuzorak igrača sa povredom skočnog $(N=44)$, sa subuzorkom igrača bez povrede skočnog zgloba $(N=51)$, moguće je zaključiti da značajne razlike nisu konstatovane u varijablama starosti, tržišne vrednosti, broja odigranih utakmica, broja postignutih golova i broja asistencija, kao ni u izvedenim varijablama vrednosti jednog igračkog dana $i$ vrednosti jedne utakmice. U osnovnim varijablama broja

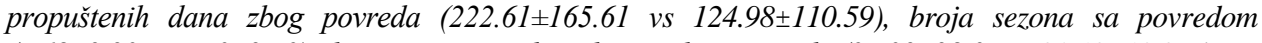

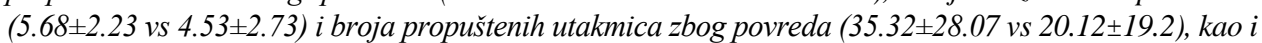

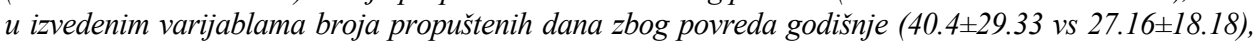

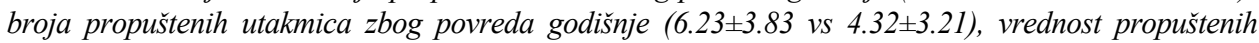


dana zbog povrede $(£ 7,627 \pm £ 5,898$ vs $£ 5,070 \pm £ 3,634)$ i vrednost propuštenih utakmica zbog povrede ( $13,134 \pm £ 12,461$ vs $£ 9,276 \pm £ 9,158)$, registrovane su statistički značajne razlike. Sve registrovane vrednosti bile su više u subuzorku igrača koji su pored ostalih povreda imali i povredu skočnog zgloba. U multivarijatnoj eksploraciji strukture osnovnih varijabli istraživanja dobijeni rezultati ukazuju na latentni prostor koji je imao interpretabilnu trodimenzionalnu struktru. Struktura prostora je ukazala na funkcionalno nezavisan odnos između učestalosti i intenziteta povređivanja, s jedne strane i hronološkog uzrasta, vrednosti transfera i igračke efiksanosti s druge. Zaključeno je da sportske povrede, a naročito povrede skočnog zgloba kod vrhunskih fudbalera imaju značajne ekonomske reprekusije.

Ključne reči: sportske povrede, uganuće skočnog zgloba, ekonomske posledice povređivanja 